\title{
Natural Products of Lactococcus Overcome Nosocomial Infection in Some of Baghdad Hospitals in Iraq
}

\author{
Yusra M.B. Mohsin \\ Enaam Hamed Bataah \\ Ali Murtatha Hasan \\ Wissam Adnan Dari* \\ Mohammed Jassim Mohammed
}

\author{
Received 13/11/2017, Accepted 29/10/2019, Published 18/3/2020
}

This work is licensed under a Creative Commons Attribution 4.0 International License.

\begin{abstract}
:
Nosocomial infections (NIs) are hospital-acquired associated infections, and also contracted due to the infections or toxins that exist in some location, like hospital. Therefore in our study, 4 Lactic acid bacteria (LAB) isolates were obtained from dairy product (Lactobacillus brevis, L. acidophilus, Lactococcus raffinolactis and Lactococcus lactis) and were tested for Bacteriocin production to select Lactococcus lactis among them. Cell free supernatant (CFS), Lipid and partial purification of protein La. Lactis had high inhibitory effect against test pathogens (E. coli, Bacillus cereus, Staphylococcus aureus and Streptococcus). 30 isolates that diagnosed by Vitec, were isolated from (3) hospitals in Baghdad/ Iraq. The results showed that the bacteriocin exhibited higher inhibition activity against the microorganisms (that isolated from hospitals), so we recommended that La. lactis is a good natural agent candidate that could be inhibitor to microorganism isolated from hospitals, so it is a good factor to decrease nosocomial infections.
\end{abstract}

Key words: Lactococcus, Nosocomial infection, Partial purification.

\section{Introduction:}

Nosocomial infections refer to health-care attributed infections and infections that require from hospital in two cases, the infection should not be found before anyone submitted to care (1). Multiple factors affect the incidence of NI such as: hand hygiene, nurse-patient ratio, safe and clean use of medical devices home of nursing, facilities of rehabilitation, clinic that visited by outpatient and other types of setting clinic, also these setting clinic that visited by susceptible patient, the infection is spread in it by many types of ways like: contaminated devices, equipment bed, tables chairs even air droplets or staff that care with health (2), due to these infections, not only the costs but also the use of antibiotics increased. In Asia, it showed that more than $40 \%$ hospitalizations with NI (3). In other side, Lactic acid bacteria (LAB) is a probiotics (Probiotics are live microorganisms that affects the host animal and improves the immune system) (4), LAB are: gram positive, non-spore forming, bacilli like Lactobacillus, and cocci like Lactococcus or rods like Pediococcus and other types, all of LAB group produce lactic acid as end products (5).

Department of Biology, College of Science, AlMustansiriyah University, Baghdad, Iraq.

*Corresponding author: wissamdari833@gmail.com

*ORCID ID: 0000-0002-1062-6555
Lactococcus has the important properties that enable it to be used as probiotics $(6,7)$.

They are ribosomal synthesized substances of proteinaceous nature, produced by $\mathrm{LAB}$ that killed or inhibited the growth of other bacteria (8). Also, LAB produce lactic acid, acetic acid, $\mathrm{H}_{2} \mathrm{O}_{2}$ and many of organic acids that have high potential of healing acute disease which are generally associated with pathogenic bacteria (9). There are many researches about these antimicrobial activity in many lines, like against UTI pathogens(10), against cosmetics bacterial contamination (11), antibacterial adherence on vaginal epithelial cell surface (12), anti-biofilm and enzyme production (virulence factors) of pathogenic bacteria $(13,14)$ respectively, also there are studies about the LAB activity against paper currency bacterial contamination in Baghdad/ Iraq (15), but there is no study regarding the $\mathrm{LAB}$ potential activity against nosocomial infections. So, we invented a way to isolate LAB from dairy products and evaluate their effect against bacteria isolated from hospitals in Baghdad to make a natural detergent agent as an alternative form from chemical detergent agents, and to avoid the negative side effect on human health and on the other side, not to give any resistant by microorganisms in future because their nature as probiotics. 


\section{Materials and Methods: Food Sample:}

Ten Samples of foods (dairy sources) were collected from the markets of Baghdad, were investigated for isolation the LAB isolates.

\section{Lactic Acid Bacteria Isolation:}

Initial dilution $\left(10^{-1}\right)$ was made by homogenization (1) $\mathrm{ml}$ of each sample and (9) $\mathrm{ml}$ of normal saline, serial dilution up to $\left(10^{-10}\right)$ was used to obtain a single colonies of LAB isolates, LAB was activated by adding $0.1 \mathrm{ml}$ from last dilution of each sample to (10) $\mathrm{ml}$ of DeMan-Rogosa-Sharpe (MRS) broth in tubes, after that, tubes homogenized by shaking and incubated in anaerobic conditions $\left(37 \mathrm{C}^{\circ}\right.$ for $\left.24 \mathrm{hrs}\right)$. MRS agar plates were cultured with (1) $\mathrm{ml}$ of bacterial dilution from each tube; also the plates were incubated under the same anaerobic conditions. Then colonies developing were picked up for microscopic diagnosis, and then fermentation by biochemical test was used for finally identification.

\section{Fermentation Medium:}

This medium was prepared according to (16), Sugars solutions (Trehalose, Xylose and Sorbitol) were sterilized by Millipore filter (0.22) and (1\%) from each solution was added to fermentation medium under sterilization conditions, change the color is an indicator for sugar fermentation. Isolates were cultured on MRS agar slant and kept in cold at $\left(4 \mathrm{C}^{\circ}\right)$ for further analysis.

\section{Lactic Acid Bacteria Ability Test for Bacteriocin Production:}

MRS broth was the medium from LAB growth, after incubation in the same anaerobic conditions, centrifugation (10.000) rpm for (10) min was made for removing the cells of LAB to each isolate, the cells in the bottom of tubes were nick led and supernatant called cell free supernatant (CFS), this supernatant was treated with $(1 \mathrm{~N})$ $\mathrm{NaOH}$ to reached the $\mathrm{pH}$ 6.5-7.0 then CFS was filtered by filter membrane $(0.22) \mu \mathrm{m}$.

CFS antimicrobial activity was determined against E.coli, Staphylococcus aureus, streptococcus, and Bacillus cereus. The inhibitory activity was tested on nutrient agar that inoculated with $(0.1) \mathrm{ml}$ of each test pathogens by spreading method after being grown in a broth overnight. Wells were made by sterilized cork borer with (70) $\mathrm{mm}$ diameter, (0.1) $\mathrm{ml}$ of CFS of each isolate filled the well and plated incubated $\left(37 \mathrm{C}^{\circ}-24 \mathrm{hrs}\right)$, measuring the diameter of inhibition zone around the wells is the marker for antibacterial activity, the $\mathrm{LAB}$ isolate showed the largest zone of Inhibition against the tested microorganisms were selected for further studies. Screening of LAB for bacteriocin production by agar well diffusion method was prepared according to (17).

\section{Partial Purification of Protein of Chosen LAB Isolate:}

Ten ml overnight culture of LAB chosen in previous tests was added to (1000) $\mathrm{ml}$ of tube that filled with MRS broth after that incubated for $24 \mathrm{hrs}$ and centrifuged at $10.000 \mathrm{xg}$ for $5 \mathrm{~min}$ at $4 \mathrm{C}^{\circ}$ to obtain cell free supernatant, then filtrated with Millipore filter paper $(0.22 \mu \mathrm{m})$ continuous shaking with gradually adding Ammonium Sulfate was done till saturation ratio (80\%) was reached (note: saturation ratio $80 \%$ means 51.6 from Ammonium Sulfate), preserved in $4 \mathrm{C}^{\circ}$ (refrigerator) for $24 \mathrm{hrs}$. The purpose of refrigeration is to get to protein precipitated, then centrifugation at $8.000 \mathrm{rpm}$ for 10 min. was done. PBS (Phosphate Buffer Saline) was used to CFS to dissolve it with ratio $1: 1$. Antibacterial activity was estimated against bacteria that isolated from nosocomial infection.

\section{Extraction of the Lipid Material from Chosen LAB Isolate:}

Ten ml overnight culture of LAB chosen from previous tests of tubes that filled with MRS broth $(1000 \mathrm{ml})$ for $24 \mathrm{hrs}$ and was centrifuged to pellet the cells at $8.000 \mathrm{rpm}$ for $10 \mathrm{~min}$ to obtain CFS. Chloroform: Methanol with same volume (1:1) were added, then left to dry the chloroform layer, the lipid layer was separated and suspended with PBS, to estimate the antibacterial activity against tested bacteria.

\section{Preparation Cell Free Supernatant (CFS):}

CFS was prepared from the chosen LAB isolate to compare the results with partially purified protein and lipid extraction. According to (13). MRS broth (500) ml incubated with chosen LAB isolate after that, it incubated in $37 \mathrm{C}^{\circ}$ for $24 \mathrm{hrs}$ under an aerobic conditions, centrifuged at $6000 \mathrm{xg}$ for $5 \mathrm{~min}$ to obtain CFS solution, filtrated by filter paper $(0.22) \mu \mathrm{m}$. Then, antibacterial activity of CFS was determined against tested bacteria.

\section{Hospitals Samples:}

In this study, thirty swap samples were taken from Al-Kindy, Ibn-Al Balady and Al-Wasity hospitals/ Baghdad/ Iraq (10 samples from each one), the samples were taken from environmental area in the hospitals like beds, tables chairs, and from different rooms. All samples were brought to the laboratory to be cultured on MacConkey, Nutrient, Blood and Mannitol agar isolation and 
identifications. All bacterial isolates obtained from cultures were identified by Vitec system in AlWahag office /Al-karrada/Baghdad/Iraq.

\section{Antibacterial Effects of Protein, Lipid and CFS of LAB Isolate:}

The antibacterial effect of protein, lipid and CFS were determined according to (18), by agar well diffusion. Muller Hinton agar medium prepared, inoculated with 0.1 of pathogenic bacteria that isolated from hospitals, and (0.1) $\mathrm{ml}$ of protein, lipid and CFS (alone) were added in each well that made by cork borer in sterilized condition. MRS was added in the fourth well to be as control, and then incubated under aerobic conditions $\left(37 \mathrm{C}^{\circ}-24\right.$ hrs), the CFS antibacterial effect determined by present the obvious inhibition zone around the wells and measure the diameter by $\mathrm{mm}$.

\section{Results and Discussion:}

Ten dairy sources used to obtain (4) isolate of LAB as shown in Table (1). According to results depicted in this Table, Lactobacillus brevis, Lactobacillus acidophilus, Lactococcus raffinolactis and Lactococcus lactis were found Table (2).

Table 1. Morphology, gram stain and biochemical tests of isolated strains of LAB.

\begin{tabular}{ccccc}
\hline Sample & $\begin{array}{c}\text { Morphology in } \\
\text { microscope(shape) }\end{array}$ & Gram stain & Catalase & Oxidase \\
\hline 1-dairy & rod shaped & + & - & - \\
2-dairy & rod shaped & + & - & - \\
3-local & cocci (aggregate) & + & - & - \\
4-local & cocci (short chain) & + & - & - \\
\hline
\end{tabular}

Table 2. Identification of LAB isolates according to the biochemical tests.

\begin{tabular}{ccccc}
\hline Isolate & \multicolumn{3}{c}{ Sugars } & Result \\
\cline { 2 - 4 } $\mathbf{1}$ & Trehalose & Xylose & Sorbitol & \\
$\mathbf{2}$ & - & - & - & Lactobacillus brevis \\
$\mathbf{3}$ & + & + & - & Lactobacillus acidophilus \\
$\mathbf{4}$ & + & $(-)$ & - & Lactococcuslactis \\
\hline
\end{tabular}

It has been reported that yogurt and local dairy are good sources to provide all the nutritional requirements for human health, because they are the source of beneficial bacteria such as Lactobacilli and Lactococci spp. which are the usual bacteria presented in yogurt and dairy products and they have beneficial characteristics and properties of the defense system in human body, our results agreed with $(19,20)$, which found that dairy products are rich with LAB and Bifidobacterium that considered as a probiotic. Three isolates of $\mathrm{LAB}$ could produce the bacteriocin during screening of their production ability, this production is diverse according to the diameter of inhibition around wells, Lactococcus lactis was the best among other LAB in bacteriocin production, (Table 3 ).

Table 3. Antibacterial activity of Lactic Acid Bacteria proteins screening against target microorganisms.

\begin{tabular}{ccccc}
\hline Test Pathogens & \multicolumn{4}{c}{ Inhibition zone (mm) } \\
\cline { 2 - 4 } E. coli & L.brevis & L.acidophilus & La. lactis & La. Raffinolactis \\
Bacillus cereus & 13 & 22 & 30 & - \\
Staphylococcus aureus & 11 & 24 & 32 & - \\
Streptococcus & 9 & 19 & 29 & - \\
\hline
\end{tabular}

In our results, L. brevis and L. acidophilus produced bacteriocin and antimicrobial activity, and thus agreed with (21), who revealed that Lactobacilli bacteriocins are among proteins that have the high activity and antimicrobial inhibition and each genus can produce more than one type of bacteriocin. La. raffinolactis did not give any inhibition activity against target microorganisms, this means that inhibitory efficacy was due to acids and not bacteriocin (22), as organic acids in LAB isolates play an important role in antimicrobial effect, because of the un dissociate feature of acid that is able to damage the cell of membrane and liberate ion of hydrogen in the cytoplasm, these factors cause cell death. So in our study, $L a$. raffinolactis lose its effects against target microorganisms due to neutralization of the acids 
with $\mathrm{NaOH}$ in methodology, at the same time it does not produce bacteriocin.

Number of similar studies have been recently reported that La. lactis produce bacteriocin in high amount $(23,24)$. La. lactis was chosen to another analysis, partial purification of protein, extraction the lipid, and production the cell free supernatant. On the other side of our study, (30) samples collected from hospitals were observed for bacterial contamination.

Streptococcus, E. coli, Klebseilla, Staphylococcus and Pseudomonas were found in these samples in large numbers, Enterococcus, Listeria were also showed a pattern of environmental bacteria species (Table 4, 5 and 6)
Table 4. Bacteria isolated from Ibn-Albalady hospital

\begin{tabular}{cl}
\hline Swaps & \multicolumn{1}{c}{ Ibn - Albalady } \\
\hline 1.bed & Enterococcus casseliflavus \\
2.bed & Enterococcus faecium \\
3.well & E.coli $(1)$ \\
4.well & E.coli $(2)$ \\
5.table & E.coli $(3)$ \\
6.table & Enterobacter cloacae \\
7.chair & Staphylococcus aureus \\
8.chair & Streptococcus thoraltensis \\
9.blanket & Listeria monocytogenes \\
10.blanket & Pseudomonas auroginosa \\
\hline
\end{tabular}

Table 5. Bacteria isolated from Al-wasitty and Al-kindy hospital.

\begin{tabular}{cll}
\hline Swaps & \multicolumn{1}{c}{ Al-wasitty } & \multicolumn{1}{c}{ Al-kindy } \\
\hline 1.bed & Staphylococcus aureus & Enterococcus faecium \\
2.bed & E.coli & Staphylococcus lentus \\
3.well & Kocuriakristinae & Staphylococcus aureus \\
4.well & Enterococcus faecium & E.coli \\
5.table & Pseudomonas stutzeri & E.coli \\
6.table & Staphylococcus epidermidis & Klebseilla \\
7.chair & Pseudomonas aeruginosa & Proteus spp. \\
8.chair & E.coli & Staphylococcus epidermides \\
9.blanket & E.coli & Streptococcus pyogenes \\
10.blanket & Bacillus mirabilis & Pantoea spp. \\
\hline
\end{tabular}

Direct contact may be the cause of transmission the infection acquired by hospital, this type of direct is being either physical or real contact of infected human, or other types of infection (25). Also the indirect contact is considered to be the second method to transfer the infection, because colonization to exited site was happened or hub of catheter, also may be due to the insertion of catheter in first week or after that in the stage of nutrition of parent real, all these reasons can be considered main factors help to spread the infection (26). Other study revealed that the nosocomial infection is caused by the misuse or over use of antibiotic that participate to incidence multi-drug resistance microorganisms contrast, minimize most kinds of unimportant drug use will reduce $60 \%$ use of the anti- anaerobic spectrum of activity (27-29). Whereas other researchers showed that there are other vectors like patients immunodifiency, medical procedures and their increasing highly and variety techniques help infection, transmission of multi-drug resistant microorganisms from patient to others in hospital, in the same time, the control practices for infection are very poor, this case and all above enable to facilitate the transmission (30-33).

Table $(6,7,8)$ show the inhibiton zones of bacterial susceptibility test of La. lactis Protein (P), Lipid (L) and cell free Supernatant (CFS), against bacterial contamination that isolated from $\mathrm{Al}-$ Kindy, which showed higher inhibiton zone than Al-Wasity and Ibn-Albalady hospitals, Figure (1-5).

Table 6. Antibacterial activity of La. lactis CFS, Lipid, Protein against bacteria (Al-Kindy hospital).

\begin{tabular}{cccc}
\hline Isolate & \multicolumn{3}{c}{ Inhibition zone of Lactococcus. Lactis } \\
\cline { 2 - 4 } & CFS & Lipid & Protein \\
Enterococcus faecium & 22 & 7 & 30 \\
Staphylococcus lentus & 18 & 9 & 29 \\
Staphylococcus aureus & 20 & 12 & 26 \\
E.coli(1) & 23 & 10 & 27 \\
E.coli(2) & 23 & 9 & 26 \\
Klebseilla & 18 & 8 & 26 \\
Proteus spp. & 17 & 10 & 28 \\
Staphylococcus epidermidis & 12 & 12 & 29 \\
Streptococcus pyogenes & 22 & 13 & 30 \\
Pantoea spp. & 23 & 19 & 31 \\
\hline
\end{tabular}


Table 7. Antibacterial activity of La. lactis CFS, Lipid, Protein against bacteria (Al-Wasity hospital).

\begin{tabular}{cccc}
\hline Isolate & \multicolumn{3}{c}{ Inhibition zone of La. lactis } \\
\cline { 2 - 4 } Staphylococcus aureus & CFS & Lipid & Protein \\
E.coli & 18 & 7 & 25 \\
Kocuriakristinae & 21 & 5 & 26 \\
Enterococcus faecium & 23 & 13 & 20 \\
Pseudomonas stutzeri & 18 & 8 & 23 \\
Staphylococcus epidermidis & 9 & 9 & 19 \\
Pseudomonas aeruginosa & 12 & 12 & 30 \\
E.coli & 22 & 19 & 15 \\
E.coli & 25 & 13 & 19 \\
Bacillus mirabilis & 13 & 8 & 25 \\
& 12 & 12 & 27 \\
\hline
\end{tabular}

Table 8. Antibacterial activity of La. lactis CFS, Lipid, Protein against bacteria (Ibn-Balady hospital).

\begin{tabular}{|c|c|c|c|}
\hline \multicolumn{4}{|c|}{ Inhibition zone of La. lactis } \\
\hline Isorate & CFS & lipid & protein \\
\hline Enterococcus casseliflavus & 16 & 12 & 29 \\
\hline Enterococcus faecium & 17 & 13 & 29 \\
\hline E.coli $(1)$ & 21 & 15 & 21 \\
\hline E.coli (2) & 25 & 9 & 25 \\
\hline E.coli (3) & 19 & 12 & 17 \\
\hline Enterobacter cloacae & 17 & 11 & 29 \\
\hline Staphylococcus aureus & 22 & 17 & 19 \\
\hline Streptococcus thoraltensis & 20 & 25 & 21 \\
\hline Listeria monocytogenes & 23 & 9 & 26 \\
\hline Pseudomonas auroginosa & 27 & 8 & 24 \\
\hline
\end{tabular}

The same Tables show that La. lactis protein had the higher activity in inhibition more than CFS and lipid, these results were similar with the previous report, where Lactococcus is the most effective against pathogenic bacteria (13).

But there is no study concerns the effect of La. lactis against nosocomial infection to compare with. However, there was no obvious difference between the effect of protein against bacteria from the three hospitals, and similar inhibition zones were also found in some of CFS and Lipid, that means the protein is more natural agent to have the efficiency to inhibit pathogenic bacteria. The effect of CFS belonged to the presence of many types of organic acids produced by LAB like acetic, lactic, propionic and other acids that act together on lowering the $\mathrm{pH}$ in the medium, so to kill the microorganisms that are unable to live in acidotic medium (34), in addition to that, the LAB can compete the other types of microbes on nutrients, because they can grow quickly than other microbes these reasons enable $\mathrm{LAB}$ to inhibit the other microorganisms (35).

Lactococcus mechanisms for inhibition the pathogens included all the reasons that mentioned above, in addition, they have specific proteins which have molecular weight ranged (5.000-7.000) $\mathrm{Da}$ and the proteins are peptide in nature and have the correlation with inhibition and death of the cells of microorganisms, this is reported by a study in vitro (36).

Whereas, another study reported that proteins have a proteinaceous nature with high inhibitory activity against pathogens by damaging the cell membrane and cell wall, these proteins are called bacteriocins (37). Also, the inhibitory compounds of Lactococcus were showen by many studies, included $\mathrm{H}_{2} \mathrm{O}_{2}$ Production that considered killer components to other microorganisms $(38,39)$. 


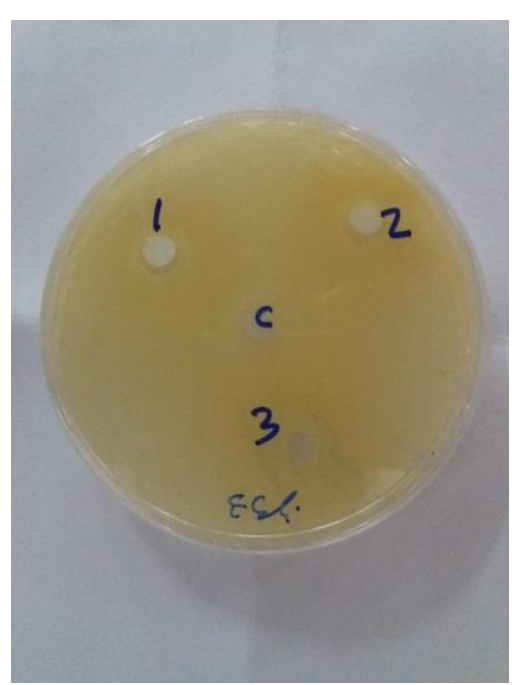

Figure 1. Antibacterial activity of La. lactis CFS, Lipid, Protein against E. coli.
1. Lipid
2. CFS
3. Protein
C. Control

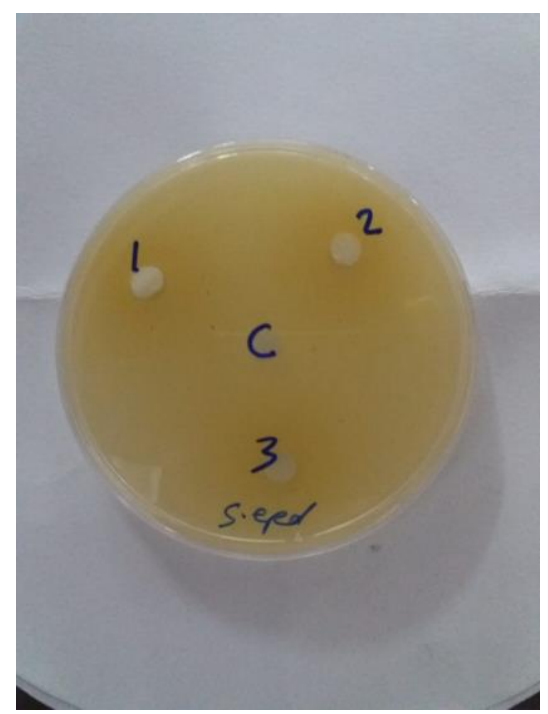

Figure 2. Antibacterial activity of La. lactis CFS, Lipid, Protein against Streptococcus.

\section{Lipid 2. CFS 3. Protein C. Control}

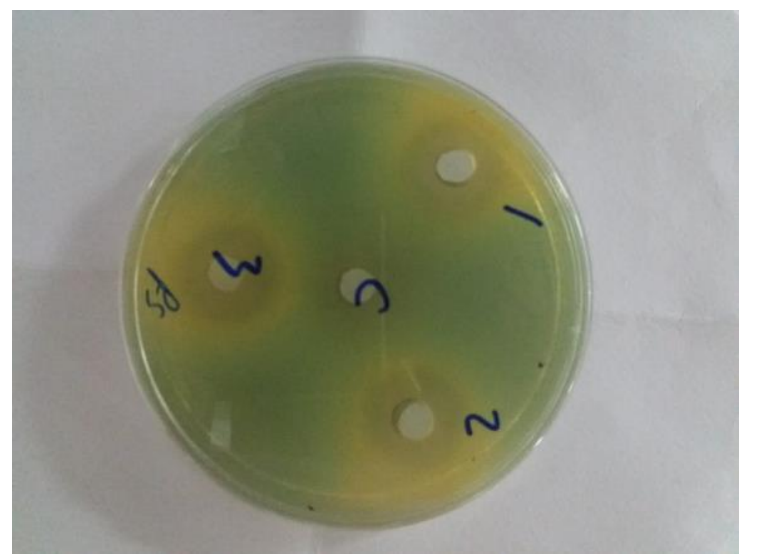

Figure 3. Antibacterial activity of La. lactis CFS, Lipid, protein against Pseudomonas.
1. Lipid
2. CFS
3. Protein
C. Control

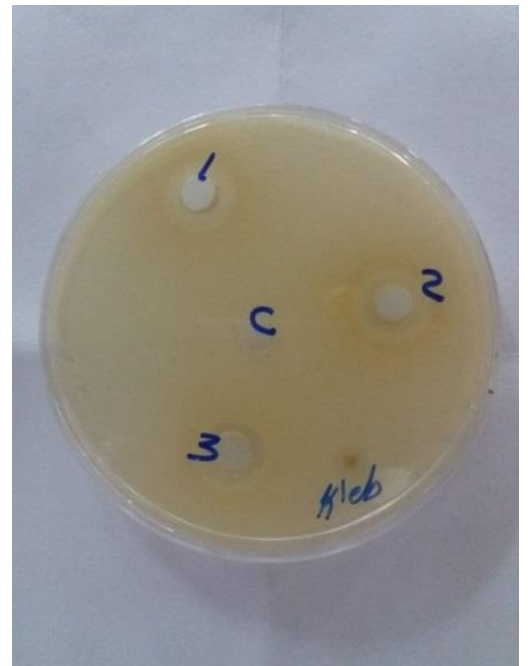

Figure 4. Antibacterial activity of La. lactis CFS, Lipid, Protein against Klebseilla.
1. Lipid
2. CFS
3. Protein
C. Control

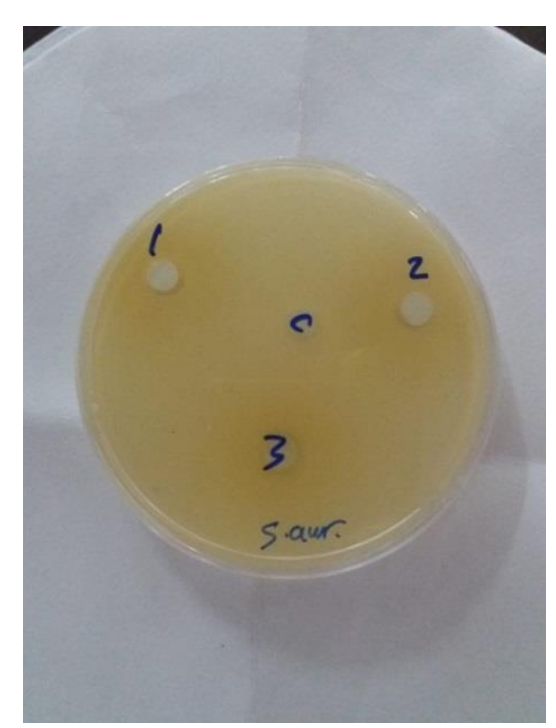

Figure 5. Antibacterial activity of La. lactis CFS, Lipid, Protein against Staphyllococcus.

\section{Lipid 2. CFS 3. Protein C. Control}

The study is extremely promising that underscores the important role of Lactococcus strains like La. lactis having the higher activity effects which may play an important role in the treatment of nosocomial infection trouble by making the natural agent that produced from this isolate as sterilization agent as an alternative from chemical agents used to sterilize the hospitals (beds, tables, and others) because of their safety and they do not increase the antibiotic resistance (by increasing the disease and using the antibiotics) compared with using the chemical ones, this is the aim of the current investigation.

\section{Conclusion:}

All of (4) LAB isolates were produced Bacteriocin except La. raffinolactis. La. lactis was 
stronger in the production of the bacteriocin. All La. lactis natural agents (Cell free supernatant, Lipid, partial purified bacteriocin) inhibit the organisms that isolated from (3) hospitals in Baghdad but. La. lactis protein was the higher in activity against all isolates and All (3) hospital was contaminated with microorganisms.

\section{Acknowledgments:}

The authors offer thanks and gratitude to Mustansiriyah University (www.uomustansiriyah.edu.iq) Iraq for their endless support in completion and complete this research.

\section{Conflicts of Interest: None.}

\section{The author has signed on animal welfare statement.}

\section{References:}

1. Navaeifar MR, Rezai MS. Device-associated nosocomial infection in children. J Pediatr Rev, 2013; 1(2): 25-41.

2. Kwak YG, Lee SO, Kim HY, Kim YK, Park ES, Jin $\mathrm{HY}$, et al. Risk factors for device-associated infection related to organizational characteristics of intensive care units: findings from the Korean Nosocomial infections Surveillance system. J hosp Infect. 2010; 75 (3): 195-199.

3. Khan HA, Ahmad A, Mehboob R. Nosocomial infections and their control strategies. Asian Pac. J. Trop. Biomed, 2015; 5 509-514.

4. Sumaira A, Javed IQ. Isolation of Acidophilic Lactis Acid Bacteria Antagonistic to Microbial Contaminants. Pakistan J. Zool, 2010; 42(5), pp. 567573.

5. Pundir RK, Rana S, Kashyap N, Kaur A. Probiotic potential of lactisacid bacteria isolated from food samples: an in vitro study.JAPS 2013; 3(3): 85-93.

6. Tambekar DH, Bhutada SA. Studies on antimicrobial activity and characteristics of bacteriocins produced by Lactobacillus strains isolate from milk of domestic animals. Internet J Microbiol, 2010A; 8:1-6.

7. Tambekar DH, Bhutada SA. An evaluation of probiotic potential of Lactobacillus sp. From milk of domestic animals and commercial avaiLABle probiotic preparations in prevention of enteric bacterial infections. Recent res. sci. technol. 2010B, 2(10): 82-88.

8. Mikkili I, Babu JD, Chaitanya M, Kodali VP. Isolation and characterization of Bacteriocin producing Lactis Acid Bacteria from curd. Int.J.Chemtech Res., 2015,8(1),Pp 388-396.

9. Khalid K, Kiong Lee HK, Zaira ZC, Khalizani K. Antimicrobial interaction of Lactococcuslactissupsp. Lactis. Against some pathogenic bacteria. Int J Biosci 2011; 1(3): 39-44.

10. Mohsen Y MB, Shawket DS, Abd-AlSattar D. Novel probiotic Bifidobacterium overcomes synergistic effect of three naturalbiotic OMNI drug and Antibiotic against some UTI pathogens. I.J.S.N., 4(3) 2013: 456-462.

11. Baqer YM, Mohammed BB, Obaid KA, Hlail ZA. CFS of Lactobacillus: A natural Agent against bacterial contamination of cosmetics tools. I.J.A.B.R, 4(3) 2014: 258-264.

12. Abbas HH, Abd-Mohammed SA, Shawkat DS, Baker YM. Effect of Lactobacillus sp. Crude Bacteriocin (CB) and Cell-Free supernatant (CFS) against E.coli growth and Adherence on Vagi Epithelial cell Surface. IJAR, 2016; 4(1): 614-620.

13. Muhsin Y MB, Majeed HZ, Shawket DS. CFS and Crude Bacteriocin of Lactococcus against Growth and Biofilm formation for some pathogenic bacteria. Int.J.Curr.Microbiol.App.Sci (2015) 4(7): 35-42.

14. Mohsin Y MB, Majeed HZ, Hassan AM, Bataah EH. Susceptibility pattern of Pseudomonas aeruginosa producing enzymes against antimicrobial agent CFS of Lactococcus with the focus on its determining quantitatively by OD (ELISA). Asian J Pharm Clin Res, Vol 10, Issue 3, 2017, 291-294.

15. Al-Fraji BM. Study of the effect selected commercial detergents (Soap, Wet wipes) and probiotic Lactobacillus against bacteria isolated from paper currencies in Baghdad, IraqIJAR 2015 3(3): 522-532.

16. Al-Jassani U. Effect of Lactobacillus filtrates in growth of some Aspergillus flavus isolated and their toxins, Thesis, College of Science, Dept. of Biology, AL-Mustansiryah University, 2006.

17. Dhewa T. Screening, production, purification and potential use of Bacteriocins from Lactis Acid Bacteria of Meat and Dairy Food Origin. International Conference on Nutrition and food Sciences, 2012; 39: 35-41.

18. Bilkova A, Sepova K, Bukovsky M, Beskova L. Antibacterial potential of Lactobacilli isolated from a lamp. Vet Med, 56, 2011 (7): 319-324.

19. Askoul I, Gorrah SA, Al-Amir L. Isolation and characterization of Bacteriocin producing Lactis Acid Bacteria from some Syrian fermented foods. Int.J.Chemtech Res., 2014; 6(4): 2507-2520.

20. Georgieva R, Yocheva L, Tserovska L, Zhelezva G, stefanova N, Atanasova A, et al. Antimicrobial activity and antibiotic susceptibility of Lactobcaillus and Bifidobacterium spp. intended for use as starter and probiotic culture. Biotechnol. Biotechnol. Equip. 2015; 29(1): 84-91.

21. Saranya S, Hemashenpagam N. Antagonistic activity and antibiotic sensitivity of Lactis Acid bacteria from fermented dairy products. Adv Appl Sci Res, 2011, 2 (4):528-534.

22. Nwuch $\mathrm{Ch}$ O. Isolation of Bacteriocin-producing Lactis acid Bacteria from Ugba and Okpiye, Two Locally fermented Nigerian food Condiments. Braz. Arch. Biol. Technol. 2013; 56(1): 101-106.

23. Djadouni F, Kihal M. Antimicrobial activity of Lactis acid bacteria and the spectrum of their biopeptides against spoiling germs in foods. Braz. Arch. Boil. Technol. 2012; 55(3): http://dx.doi.org.

24. Fan L, Song J. Antimicrobial microbes-bacteriocin producing Lactis acid bacteria, Microbial pathogens 
and strategies for combating them: science, technology and education (A. Méndez-Vilas, Ed.) formatex, 2013; 899-909.

25. Allegranzi B, Sax H, Bengaly L, Richet H, Minta D, Chraiti M, et al. Successful implementation of world health organization hand hygiene improvement strategy in a referral hospital in Mali, Africa. Infection control and hospital epidemiology: world Health Organization "Point G" project Management Committee, Infect Control Hosp Epidemiol, 2010; 31(2): 133-41. doi: 10.1086/649796.

26. Acosta-Gnass S, Stempliuk V. Sterilization manual for health centers: pan American Health Organization.Medical, 2010; 167 pages.

27. Umscheid C, Rajender-Agarwal M, Kendal-Williams M, Brennan P. Estimating the proportion of health care-associated infections that are reasonably preventable and the related mortality and costs. The official Infect Control Hosp Epidemiol, 2011; 32(2): 101-11428.

28. Nejad S, Allergranzi B, Syed S, Ellis B, pittet D. Health-care-associated infection in Africa: a systematic review. Bull World Health Organ. 2011; 89(10): 757-765.

29. Rosenthal V, Todi S, Alvarez-Moreno C, Pawar M, karlekar A, Zeggwagh A. Impact of multidimensional infection control strategy on catheter-associated urinary tract infection rates in the adult intensive care units of 15 developing countries: findings of the International Nosocomial infection control consortium (INICC)., Infection, 2012; 40(5): 517526.

30. Januel J, Harbarth S, Allard R, Voiriv N, Lepape A, Allaouchiche B, et al. Estimating attribute table mortality due to nosocomial infections acquired in intensive care units. Infect Control Hosp Epidemiol, 2010; 31(4): 388-394.

31. Reunes S, Rombaut V, Vogelaers D, Brusselaers N, Lizy C, Cankurtaran M, et al. Risk factors and mortality for nosocomial bloodstream infections in elderly patients. Eur J Intern Med2011; 22(5): 39-44.

32. Tao L, Hu B, Rosenthal V, Zhang Y, Gao X, He L. Impact of a multidimensional approach on ventilatorassociated pneumonia vote in a hospital of shanghai: Finding of the International Nosocomial Infection Control Consortium. J Crit Care, 2012; 27(5): 440446.

33. Bilavsky E, Pfeffer I, Tarabeia J, Schechner V, AbuHanna J, Grisaru-Soen G, et al. Outbreak of multidrug-resistant Pseudomonas aeruginosa infection following urodynamic studies traced to contaminated transduce. JHI 2013; 83(4).DOI: 10.1016/j.jhin.2013.01.003.

34.34.Beesam S, Thirtham MR, Komireddy KR, Venkata MR. Evaluation of probiotic characteristics in certain lactic acid bacteria strains by in vitro techniques. ABI. 2012;1(2):149-51. 35.Rauta P, Dhupal M, Nayak B. Screening and characterization of potential probiotic Lactis acid bacteria isolated from vegetable waste and fish intestine. Int. J. Curr. Microbiol.Appl.Sci. 2013; 2(8): 234-244.

35.36.Ahmed A. In vitro screening of Lactobacillus sp. From homemade yoghurt for antagonistic effects against common bacterial pathogens. JJBS, 2013; 6(3): 211-213.

36. 37.Giang H, Viet T, Ogle B, Linderg J. Effects of supplementation of probiotics on the performance, nutrient digestibility and fecal micro flora in Growing-finshing pigs, Asian-Aust. J. Anim. Science, 2010; 24(5): $655-661$.

37.38.Rattanachaikunsopon P, Phumkhachorn P. Lactis acid bacteria: their antimicrobial compound and their uses in food production. Ann. Biol. Sci., 2010, 1 (4):218-228.

38. 39.Sarkono F, Sofyan Y. Isolation and Identification of lactis acid bacteria from abalone (Haliotisasinina) as a potential candidate of probiotic. Biosic. Biotechnol. Biochem., 2010 2: 38-42.
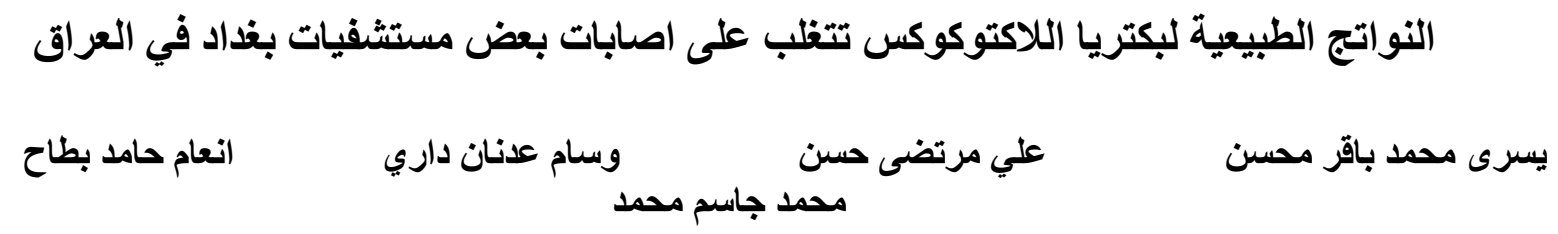

$$
\text { قسم علوم الحياة، كلية العلوم، الجامعة المستنصرية، بغداد، العراق. }
$$

عدوى المستشفيات (NIS) هي العدوى المرتبطة المكتسبة بالمستشفى، وتعزى ايضا سبب الاصنابة بالعدوى الى وجود السموم في

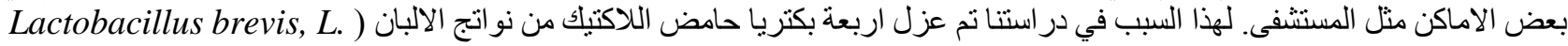
(acidophilus, Lactococcus raffinolactis, Lactococcus lactis من بين المجموعة. كان عالق الخلايا الحر، الدهن و التنقية الجزيئة لبروتين Lactococcus lactis

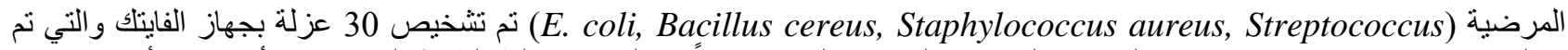

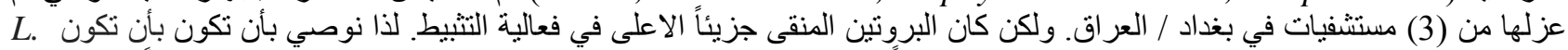

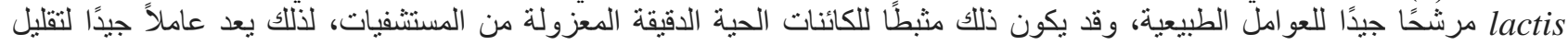
الإصابة بالعدوى. 